\title{
ARC. GIS Based Interpretation of Ground Water Pollution: A Case Study of Coastal Area District Badin, Sindh, Pakistan
}

\author{
Mohammad Amin Qureshi ${ }^{*}$, Ghulam Murtaza Mastoi, Abdul Aziz Mastoi, Muhammad Ali Bhatti, \\ Ali Muhammad Rind, Saima Chandio, Abdul Waheed Mastoi
}

Centre for Environmental Sciences, University of Sindh, Jamshoro, Sindh, Pakistan

Email address:

m-ameen-q@hotmail.com (M. A. Qureshi)

\section{To cite this article:}

Mohammad Amin Qureshi, Ghulam Murtaza Mastoi, Abdul Aziz Mastoi, Muhammad Ali Bhatti, Ali Muhammad Rind, Saima Chandio, Abdul Waheed Mastoi. ARC. GIS Based Interpretation of Ground Water Pollution: A Case Study of Coastal Area District Badin, Sindh, Pakistan. Hydrology. Vol. 3, No. 2, 2015, pp. 11-21. doi: 10.11648/j.hyd.20150301.12

\begin{abstract}
The border line of Arabian Sea, near district Badin, Sindh, Pakistan was selected as a case study for the investigation of heavy metal concentration in ground water. Ground water is used for human consumption as well as agricultural purposes due to shortage of fresh water in the area. Badin Coastal area is poverty stricken, socio-economically backward, politically ignored, frequently affected and hit by natural disasters. Area is known by stormy cyclones, monsoon heavy rains, floods, tidal sea water intrusion and sea erosion. Study area has not been highlighted properly yet. Highly polluted waste water of Mega project Left Bank Outfall Drain (LBOD) which carries complexes of pollutants of agriculture run off, industrial and municipal effluents of different districts, are being disposed into Arabian Sea, passing through coastal areas of district Badin, contaminating lakes, lagoons, ground water and soils. Tidal sea water of Arabian Sea also pollutes ground water through seepage. The attempts were made to understand the effects on ground drinking water and results were interpreted by Arc GIS maps, to meet the current trends of research. The objective was to investigate ground water pollution extent in the area due to drains and tidal sea water. Sixteen (16) samples of ground water were collected from different villages near coastal area. The average data of various parameters of ground water near coastal were: $\mathrm{pH} 7.40 \pm 0.3758$, E.C $(\mathrm{ms} / \mathrm{cm}) 7.45 \pm 6.8166$,

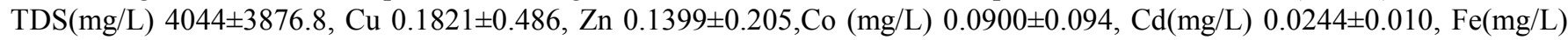
$0.3260 \pm 0.591, \mathrm{Ni}(\mathrm{mg} / \mathrm{L}) \quad 0.0055 \pm 0.012, \mathrm{~Pb}(\mu \mathrm{g} / \mathrm{L}) 0.1312 \pm 0.144$. The evaluated results indicated that Left Bank Outfall Drain and sea water intrusion are major contributor for ground water pollution and ground water was found to be unfit for drinking purposes.
\end{abstract}

Keywords: Ground Water, Coastal Area, Badin, GIS (Geographic Information System), Saline Intrusion, Drains, Left Bank Outfall Drain (LBOD), Run Kutch, Lagoons

\section{Introduction}

Pakistan is facing a major problem of groundwater pollution. Groundwater is the major source for agriculture and drinking in Pakistan. Groundwater contamination is a major problem due to disposal of urban, industrial wastes and agricultural chemicals[1].It is reported that nearly $40 \%$ adult and $60 \%$ infant deaths occurs due to poor quality of drinking water in back word countries. Pakistan's $60 \%$ population is deprived of availability of safe water till present [2, 3]. The increasing urbanization, inappropriate dumping of solid and liquid wastes, have resulted in the deterioration of ground water quality in Pakistan [4].

The coastal district of Badin stretches to Arabians Sea and is a very vulnerable region. Coastal area of Badin faces shortage of irrigation and drinking water since decades. This shortage of water has forced people to use ground water irrespective of its quality. The Badin coastal area has low quality of ground water due to disposal of agrochemicals through agriculture run off, industrial and municipal liquid wastes as well as Sea tidal water [5]. When ground water is not recharged by canal water, then the gap is filled by sea intrusion converting sweet water into brackish one. Ecology of coast has deteriorated due to introduction of Mega drainage canal network (Fig1) Left Bank Outfall Drain 
(LBOD), carrying industrial, agricultural runoff and municipal waste water of different districts $[6,7]$. There has been extreme need of work to be done regarding ground water study over GIS based mapping. The objective of the present study was to carry out investigations of the groundwater quality, to make a base line data, and highlight severe conditions to the concerned authorities. The obtained results of coastal area of Badin were interpreted using GIS software.
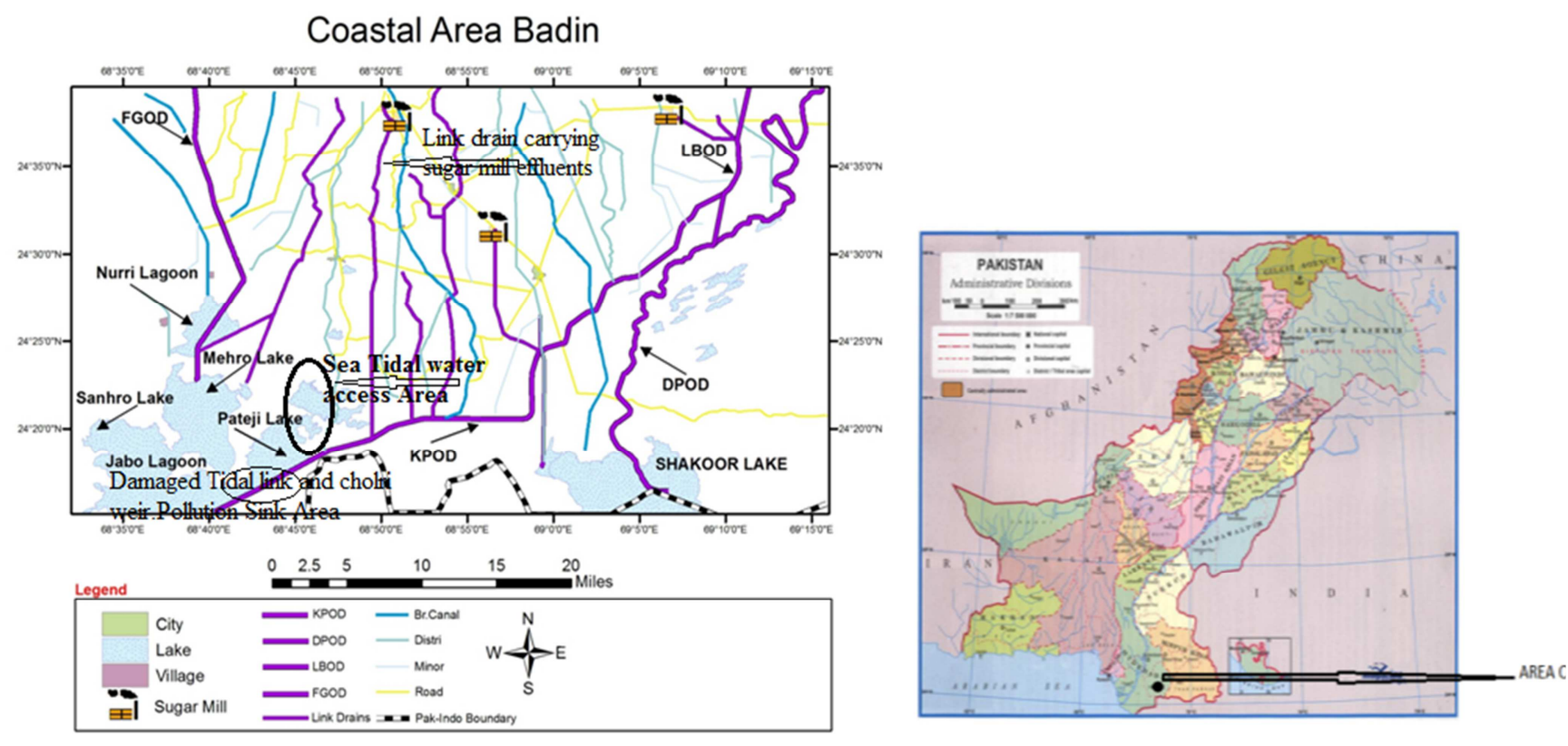

Fig. 1. showing map of coastal district Badin.

\section{Methodology}

\subsection{Historical Back Ground Area of Study}

The coastal district of Badin is situated at $24^{\circ}-5^{\prime}$ to $25^{\circ}-25^{\prime}$ north latitude and $6821^{\prime}$ to 6920 ' east longitude [8]. The district is bordered in south with the Arabian Sea. Agriculture and agro based industry is the main source of economy of Badin. Coastal area of Badin is considered as a pollution sink.

Prior to the construction of Ghulam Mohammad Barrage, coastal area of Badin was one of fertile parts of the Indus delta. Annual floods had not only maintained ecology but also kept sea water away. But after the construction of Barrage (flood protected embankment) in 1955, the area was completely cut off and coastal ecosystem started degrading and soon turned into a saline desert $[9,6,7,8]$.

After 1960 it was observed that coastal area had shrinked due to complete isolation from delta ecosystem and new saline lakes appeared, on older deltic depressions due to tidal water. Reduction in stream flow caused sea water inundation in the low lying lands up to the depth of 5 to 6 meters by high tides and cyclones $[6,7,9]$.

To the south eastern side of coastal district is a huge desert named Run Kutch sharing borders with both Pakistan and India. Geological survey of Pakistan has termed this region within seismic region 2, indicating minor to moderate seismic hazard. Orientation of Run Kutch fault is $225 \mathrm{~km}$ in length causing earth quake of a magnitude of $7.6 \mathrm{M}$ on Richter scale. Earthquake of 2001 revealed eastward running of ground sea water [9].
The coastal district Badin has been main area for Oil and gas exploration and production since1981.At present oil exploring companies have been permitted to work in Ramsar recognized wetland areas like Jubho and Nurri Lagoons of Badin district [9], although activities such as mining are prohibited in national parks. Wildlife sanctuaries are supposed to be undisturbed breeding grounds, just as cultivation and grazing is prohibited in the demarcated areas. But in 2001 government allowed oil and gas exploring activities within national parks and wildlife sanctuaries by an ordinance [9]. Oil and gas exploration has negative impacts on the environment.

Ecology of Badin has changed due to imbalance of water supply mostly excess of polluted water supply. The conditions have deteriorated due introduction of two drainage system in 1960s and 1980s.One,Kotri barrage drain system comprises of KaroGungro and FuleliGuni Outfall drains, both drains, polluting coastal wetland like Sanhro, Mehro and Cholri shallow lakes. Second is, Left bank outfall drain (LBOD) which ends into Arabian Sea (Fig.1).LBOD has four other components like KadhanPateji outfall drain (KPOD), Dhoropuran outfall drain (DPOD), Tidal Link and Cholri weir[6,7]. Both drains carry agriculture run off, industrial and municipal waste of different districts. Due to poor infrastructure of drains, all coastal areas get contaminated by the polluted water of LBOD (Fig.1). Backflow of contaminated water by tidal water of sea through the same drains contributes to coastal pollution [7].

At the same time, Badin district has very poor socioeconomic conditions, lacking in basic infrastructure, 
with poor education and health facilities, reducing agriculture, livestock and fish catch, with almost no alternatives.

\subsection{Sample Collection}

Ground water samples were collected from sixteen (16) selected villages near coastal area of district Badin, where hand pumps were in use to fetch water. Samples were collected between $1^{\text {st }}-3^{\text {rd }}$ February 2012.Samples were collected in $1.5 \mathrm{~L}$ plastic bottles which were cleaned, well washed and rinsed. Electric conductivity, total dissolved salts and $\mathrm{pH}$ were recorded on the spot by using pre calibrated Orion 115 conductivity meter and Orion 420A pH meter respectively. Latitude and longitude were recorded using GPS eTrex Legend Garmin. The concentration of Iron, Copper, Zinc, Cadmium, Nickel,Cobalt and Lead were determined using Flame Atomic Absorption Spectrophotometer (FAAS) [10].

Arc GIS software 9.2 software was used for analyzing, mapping and interpretation of data $[11,12]$. With the utilization of coordinates of GPS of the sampling locations, a point feature showing the position of the ground water sampling area was prepared. Kml files after using GPS coordinates were developed and exported to GIS (arc map). Water quality parameters with their results were stored as attribute table data in Arc Map as shape files. The values obtained were categorized into different classes and represented with graduated color circles by using symbology option. Mostly values within permissible limits were indicated by green color circles while concentration beyond permissible values highlighted with red color circles. Parameters of zero value (not detected) are shown in white circle.

\section{Result and Discussions}

\section{1. $\mathrm{pH}$}

$\mathrm{pH}$ usually has no direct impact on consumers; it is one of the most important operational water quality parameters. The optimum $\mathrm{pH}$ required will vary in different supplies according to the composition of the water and the nature of the construction materials used in the distribution system; it is usually in the range $6.5-8.5$. No health-based guideline value has been proposed for $\mathrm{pH}$, but acceptable limit is $6.5-$ 8.5) for drinking water [13].The result of $\mathrm{pH}$ shown in (table1\&2) indicated $\mathrm{pH}$ of sampling areas was within range of $6.78-8.18$.The average ph range was 7.40 . The $\mathrm{pH}$ of sample locations was within acceptable limits of WHO (6.5 8.5) for drinking.

Table 1. Showing heavy metal results of ground water near coastal area of Badin.

\begin{tabular}{|c|c|c|c|c|}
\hline S.NO & Sampling locations & & & \\
\hline 1 & Sample code & S-1 & S-2 & S-3 \\
\hline 2 & Location & Sahib Khan & Golo Mandhro & A. G. Mallah \\
\hline 3 & Latitude & $\mathrm{N} 24^{\circ}$ to 27.292 & $\mathrm{~N} 24^{\circ}$ to 22.535 & $\mathrm{~N} 24^{\circ}$ to 25.024 \\
\hline 4 & Longitude & E $068^{\circ}$ to 47.624 & E $068^{\circ}$ to 47.343 & E $068^{\circ}$ to 47.975 \\
\hline 5 & $\mathrm{pH}$ & 7.67 & 7.2 & 7.09 \\
\hline 6 & $\mathrm{EC}(\mathrm{mS} / \mathrm{cm})$ & 9.9 & 8.7 & 6.84 \\
\hline 7 & TDS (mg/L) & 5430 & 4750 & 3600 \\
\hline 8 & $\mathrm{Cu}(\mathrm{mg} / \mathrm{L})$ & 0.032 & 0.0137 & 0.0505 \\
\hline 9 & $\mathrm{Zn}(\mathrm{mg} / \mathrm{L})$ & 0.8106 & 0.2385 & 0.1355 \\
\hline 10 & $\mathrm{Co}(\mathrm{mg} / \mathrm{L})$ & 0.2198 & 0.1848 & 0.1877 \\
\hline 11 & $\mathrm{Cd}(\mathrm{mg} / \mathrm{L})$ & 0.0281 & 0.0308 & 0.0256 \\
\hline 12 & $\mathrm{Ni}(\mathrm{mg} / \mathrm{L})$ & N.D & N.D & N.D \\
\hline 13 & $\mathrm{Fe}(\mathrm{mg} / \mathrm{L})$ & 2.334 & 0.914 & 0.2517 \\
\hline 14 & $\mathrm{~Pb}(\mu \mathrm{g} / \mathrm{L})$ & 0.2 & 0.3 & 0.2 \\
\hline
\end{tabular}

Table 1. Continue.

\begin{tabular}{|c|c|c|c|c|c|}
\hline \multirow{2}{*}{$\begin{array}{l}\text { S.NO } \\
1\end{array}$} & \multicolumn{5}{|c|}{ Sampling locations } \\
\hline & Sample code & S-5 & S-6 & S-7 & S-8 \\
\hline 2 & Location & Muhar Pali & Arab Nodani & Dinar Talpur & Bughra Memon \\
\hline 3 & Latitude & $\mathrm{N} 24^{\circ}$ to 25.439 & $\mathrm{~N} 24^{\circ}$ to 29.319 & $\mathrm{~N} 24^{\circ}$ to 24.436 & $\mathrm{~N} 24^{\circ}$ to 24.282 \\
\hline 4 & Longitude & E $068^{\circ}$ to 48.135 & E $068^{\circ}$ to 47.599 & E $068^{\circ}$ to 47.858 & E $068^{\circ}$ to 46.906 \\
\hline 5 & $\mathrm{pH}$ & 7.62 & 7.24 & 8.18 & 7.41 \\
\hline 6 & $\mathrm{EC}(\mathrm{mS} / \mathrm{cm})$ & 5.62 & 3.12 & 2.48 & 3.12 \\
\hline 7 & TDS (mg/L) & 2950 & 1560 & 1230 & 1570 \\
\hline 8 & $\mathrm{Cu}(\mathrm{mg} / \mathrm{L})$ & 0.0128 & 0.0312 & 0.1369 & 0.0019 \\
\hline 9 & $\mathrm{Zn}(\mathrm{mg} / \mathrm{L})$ & 0.1245 & 0.1343 & 0.1771 & 0.0719 \\
\hline 10 & $\mathrm{Co}(\mathrm{mg} / \mathrm{L})$ & 0.1799 & 0.1519 & 0.1561 & 0.1841 \\
\hline 11 & $\mathrm{Cd}(\mathrm{mg} / \mathrm{L})$ & 0.0286 & 0.0258 & 0.0281 & 0.0266 \\
\hline 12 & $\mathrm{Ni}(\mathrm{mg} / \mathrm{L})$ & N.D & N.D & N.D & N.D \\
\hline 13 & $\mathrm{Fe}(\mathrm{mg} / \mathrm{L})$ & 0.1775 & 0.172 & 0.62 & 0.073 \\
\hline 14 & $\mathrm{~Pb}(\mu \mathrm{g} / \mathrm{L})$ & 0.2 & 0.2 & 0.3 & 0.3 \\
\hline
\end{tabular}


Table 2. Showing heavy metal results of ground water near coastal area of Badin.

\begin{tabular}{|c|c|c|c|c|c|c|}
\hline \multirow{2}{*}{$\begin{array}{l}\text { S.NO } \\
1\end{array}$} & \multicolumn{6}{|c|}{ Sampling locations } \\
\hline & Sample code & S-9 & S-10 & S-11 & S-12 & S-13 \\
\hline 2 & Location & Village Ahmed Rajo & Village Allah Dino Mallah & Village Lakho Peer & Village Bahedmi & Kadhan City \\
\hline 3 & Latitude & $\mathrm{N} 24^{\circ}$ to 26.063 & $\mathrm{~N} 24^{\circ}$ to 23.770 & $\mathrm{~N} 24^{\circ}$ to 23.343 & $\mathrm{~N} 24^{\circ}$ to 23.736 & $\mathrm{~N} 24^{\circ}$ to 28.683 \\
\hline 4 & Longitude & $\mathrm{E} 068^{\circ}$ to 37.380 & E068 to ${ }^{\circ} 35.718$ & $\mathrm{E} 068^{\circ}$ to 52.725 & $\mathrm{E} 068^{\circ}$ to 55.907 & $\mathrm{E} 068^{\circ}$ to 59.154 \\
\hline 5 & $\mathrm{pH}$ & 7.10 & 7.48 & 7.24 & 6.82 & 6.78 \\
\hline 6 & $\mathrm{EC}(\mathrm{mS} / \mathrm{cm})$ & 3.43 & 10.27 & 7.90 & 4.58 & 15.80 \\
\hline 7 & TDS (mg/L) & 1740 & 5650 & 4260 & 2360 & 8910 \\
\hline 8 & $\mathrm{Cu}(\mathrm{mg} / \mathrm{L})$ & 0.2723 & 0.1307 & 0.0536 & N.D & 1.987 \\
\hline 9 & $\mathrm{Zn}$ & 0.0469 & 0.0067 & 0.0262 & 0.0339 & 0.0307 \\
\hline 10 & $\mathrm{Co}(\mathrm{mg} / \mathrm{L})$ & N.D & N.D & N.D & N.D & N.D \\
\hline 11 & $\mathrm{Cd}(\mathrm{mg} / \mathrm{L})$ & 0.0157 & 0.0105 & 0.0236 & 0.036 & 0.0473 \\
\hline 12 & $\mathrm{Ni}(\mathrm{mg} / \mathrm{L})$ & N.D & 0.0292 & N.D & N.D & 0.0349 \\
\hline 13 & $\mathrm{Fe}(\mathrm{mg} / \mathrm{L})$ & 0.0260 & 0.0343 & 0.0066 & 0.0150 & 0.3128 \\
\hline 14 & $\mathrm{~Pb}(\mu \mathrm{g} / \mathrm{L})$ & N.D & N.D & N.D & N.D & N.D \\
\hline
\end{tabular}

Table 2. Continue.

\begin{tabular}{|c|c|c|c|c|c|c|c|}
\hline S.NO & Sampling loc & ons & & & \multirow{5}{*}{ AVERAGE } & \multirow{5}{*}{ ST.DEV } & \multirow[b]{2}{*}{ WHO permissible } \\
\hline 1 & Sample code & S-14 & S-15 & S-16 & & & \\
\hline 2 & Location & Serani City & Village Gul shah & Village Ali Mohmmdmallah & & & limit for drinking \\
\hline 3 & Latitude & $\mathrm{N} 24^{\circ}$ to 29.702 & $\mathrm{~N} 24^{\circ}$ to 28.858 & $\mathrm{~N} 24^{\circ}$ to 20.710 & & & water \\
\hline 4 & Longitude & $\mathrm{E} 068^{\circ}$ to 47.623 & E068 ${ }^{\circ}$ to 47.885 & E068 $8^{\circ}$ to 47.377 & & & \\
\hline 5 & $\mathrm{pH}$ & 7.70 & 7.88 & 7.64 & 7.40 & 0.3758 & $6.5-8.5^{*}$ \\
\hline 6 & $\mathrm{EC}(\mathrm{mS} / \mathrm{cm})$ & 1.04 & 1.425 & 28.5 & 7.45 & 6.8166 & $0.4^{*}$ \\
\hline 7 & TDS (mg/L) & 506 & 694 & 16000 & 4044 & 3876.8 & $1000^{*}$ \\
\hline 8 & $\mathrm{Cu}(\mathrm{mg} / \mathrm{L})$ & 0.0824 & 0.0640 & 0.0242 & 0.1821 & 0.486 & 2 \\
\hline 9 & $\mathrm{Zn}$ & 0.0156 & 0.0084 & 0.0064 & 0.1399 & 0.205 & $4^{*}$ \\
\hline 10 & $\mathrm{Co}(\mathrm{mg} / \mathrm{L})$ & N.D & N.D & N.D & 0.0900 & 0.094 & * NGV \\
\hline 11 & $\mathrm{Cd}(\mathrm{mg} / \mathrm{L})$ & 0.0112 & 0.0154 & 0.0082 & 0.0244 & 0.010 & 0.003 \\
\hline 12 & $\mathrm{Ni}(\mathrm{mg} / \mathrm{L})$ & N.D & N.D & 0.0252 & 0.0055 & 0.012 & 0.07 \\
\hline 13 & $\mathrm{Fe}(\mathrm{mg} / \mathrm{L})$ & 0.0254 & 0.0187 & 0.0024 & 0.3260 & 0.591 & $0.3 *$ \\
\hline 14 & $\mathrm{~Pb}(\mu \mathrm{g} / \mathrm{L})$ & N.D & N.D & N.D & 0.1312 & 0.144 & $10(\mu \mathrm{g} / \mathrm{L})$ \\
\hline
\end{tabular}

* NGV (No health-based guideline value recommended by WHO2011), *(acceptable value recommended by WHO2011), N.D (Not detected)

Coastal Area Badin

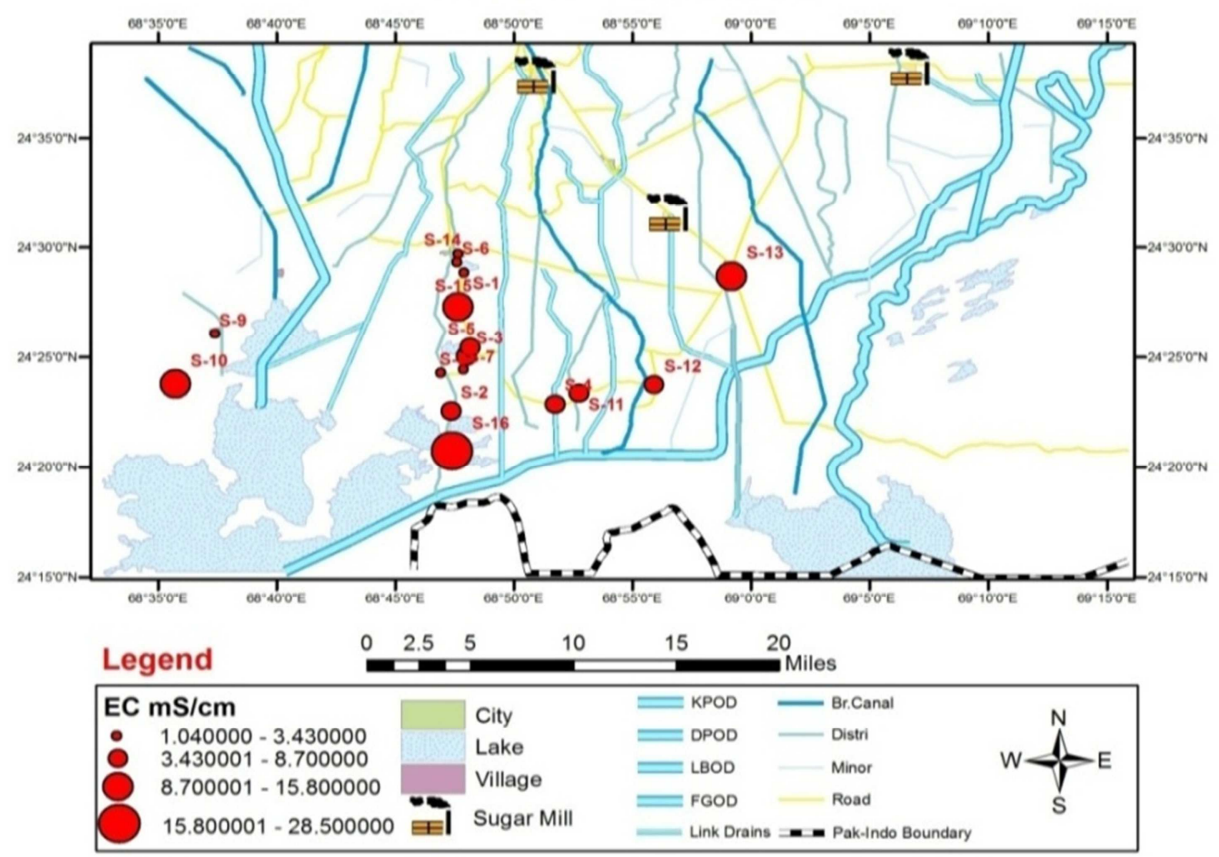

Fig. 2. Map showing detection of E.C. 


\subsection{E.C}

The permissible limit of Electric conductivity of WHO for drinking water is $0.4 \mathrm{mS} / \mathrm{cm}$ [13].The results of electric conductivity are shown in Fig.2, values are represented with red graduated circles. The EC results ranges from 1.04 $28.5 \mathrm{mS} / \mathrm{cm}$. Sample location S-16 showed maximum value of E.C, being closer to sea Coastal water. Majority of sampling villages confirmed that water was no more consumed for potable purposes. The values of E.C (1.04 to $28.5 \mathrm{mS} / \mathrm{cm})$ were higher than threshold limits of WHO $(0.4 \mathrm{mS} / \mathrm{cm})$ for drinking (Table 2). It is confirmed that ground water of the coastal areas have been polluted by seawater. Our results of EC of ground water samples are confirmed by the results of Memon et al. 2010.

\subsection{TDS}

Total dissolved solids (TDS) comprise inorganic salts (calcium, magnesium, potassium, sodium, bicarbonates, chlorides and sulfates) and small amounts of organic matter that are dissolved in water. TDS in drinking-water originates from natural sources, sewage, urban runoff and industrial wastewater. Total dissolved solids (TDS) less than about600 $\mathrm{mg} / \mathrm{l}$ is generally considered to be good. Drinking-water becomes unpleasant at TDS levels greater than $1000 \mathrm{mg} / \mathrm{l}$. No health-based guideline value for TDS has been proposed by WH0 .TDS when reaches at level of $3500 \mathrm{mg} / \mathrm{L}$ water is termed as brackish and when it crosses the range of 5000 $\mathrm{mg} / \mathrm{L}$ termed as saline one.

The results of TDS as shown in Fig. 3 are represented in graduated red circles. The values of TDS were within range from $506-16000 \mathrm{mg} / \mathrm{L}$. The results of TDS were higher than permissible limits $(1000 \mathrm{mg} / \mathrm{L})$ of WHO for drinking water in $87.5 \%$ samples. Sample location S-16, had high value of TDS, being closer to tidal water. High values of TDS confirmed that ground water has been severely affected by sea water intrusion and saline water carried by LBOD. It was also observed that sampling locations having TDS above $3000 \mathrm{mg} / \mathrm{L}$ were not used for drinking purposes but the water was being used for cattle and domestic consumption.

\section{Coastal Area Badin}

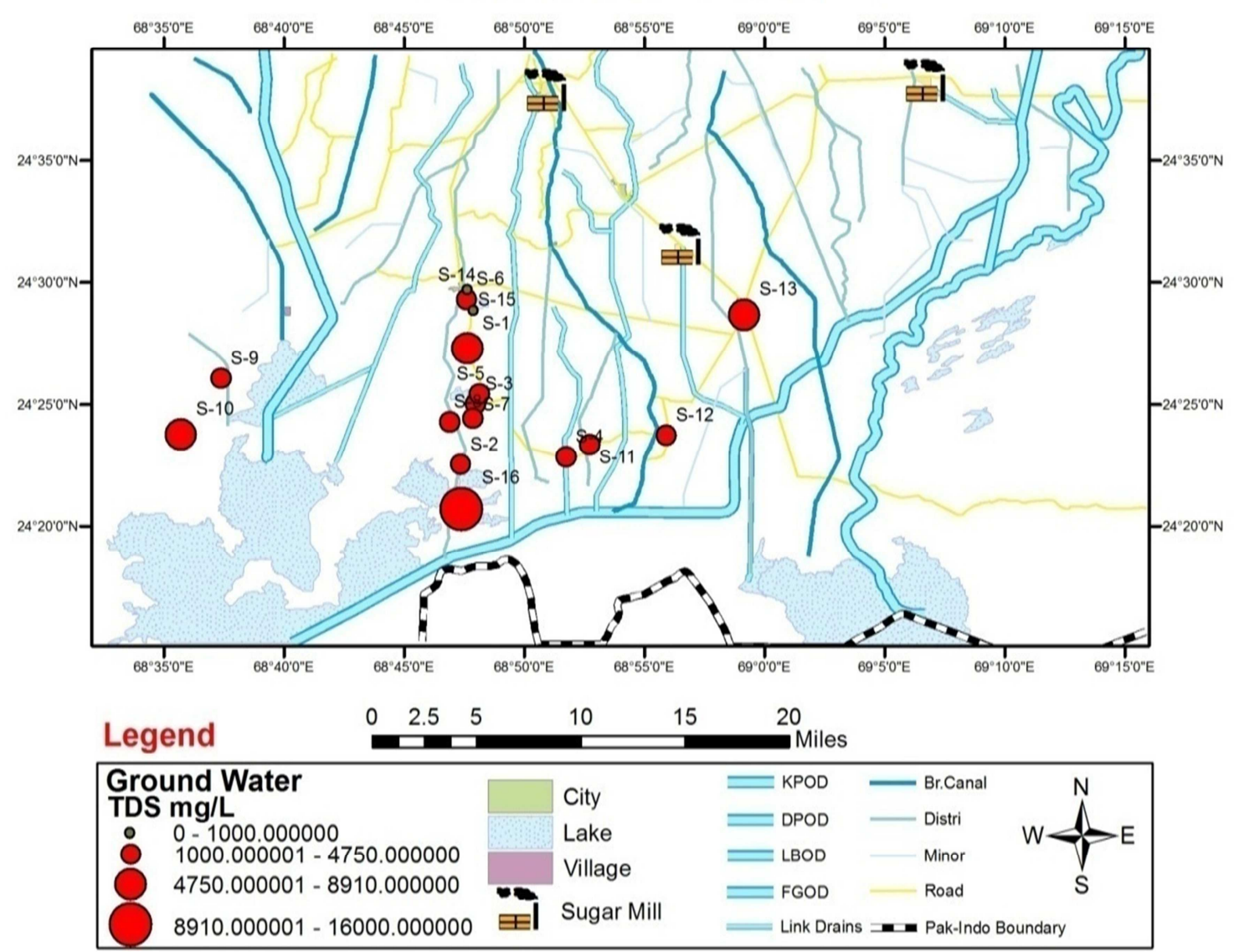

Fig. 3. Map showing detection of TDS.

\subsection{Copper}

Copper is present in natural water in smaller quantities. Copper deficiency results in growth inhibition, anemia and loss of hair pigment. Mostly contamination of water of copper occurs due to untreated industrial wastewater pollution [14]. The contamination of copper in drinking water also occurs due to corrosion of the copper pipes or fittings. The high level of copper beyond the permissible limit can cause a bitter metallic taste in water and results in 
blue-green stains on plumbing fixtures. Intestinal distresses such as nausea, vomiting, diarrhea, and stomach cramps are the health problems associated with copper contamination in water. Copper is also an essential, micronutrient and is required by the body in very small amounts $[15,16]$. The maximum permissible limit for copper recommended by
WHOare $3 \mathrm{mg} / \mathrm{L}$ [13] . The results of the concentration of copper shown in Fig. 4, highlighted with graduated green circles. All values of copper $(0.032-1.98 \mathrm{mg} / \mathrm{L})$ were found to be within WHO permissible limits $(2 \mathrm{mg} / \mathrm{L})$ for drinking water in the areas of study. Maximum copper concentration was found near S-13 sampling area.

Coastal Area Badin
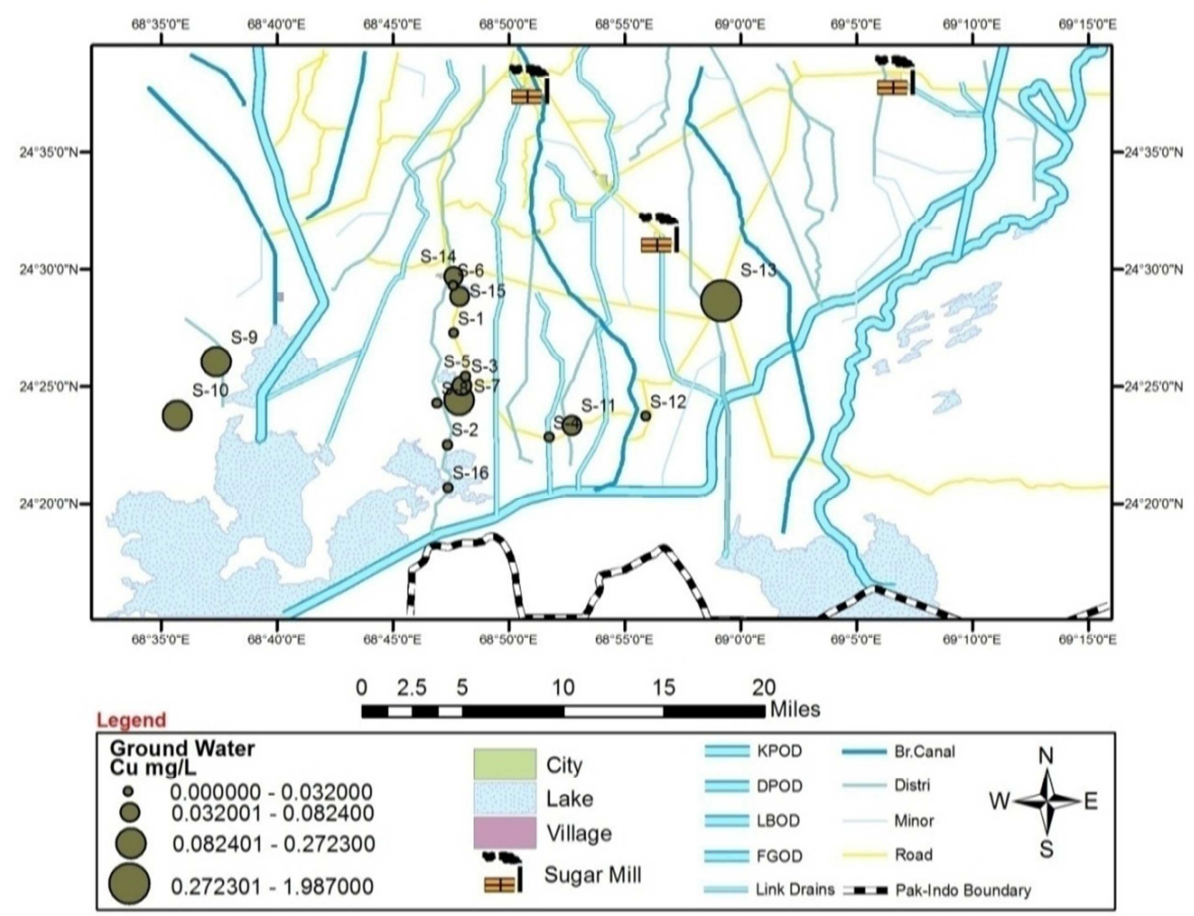

Fig. 4. Map showing detection of Copper.

\section{Coastal Area Badin}

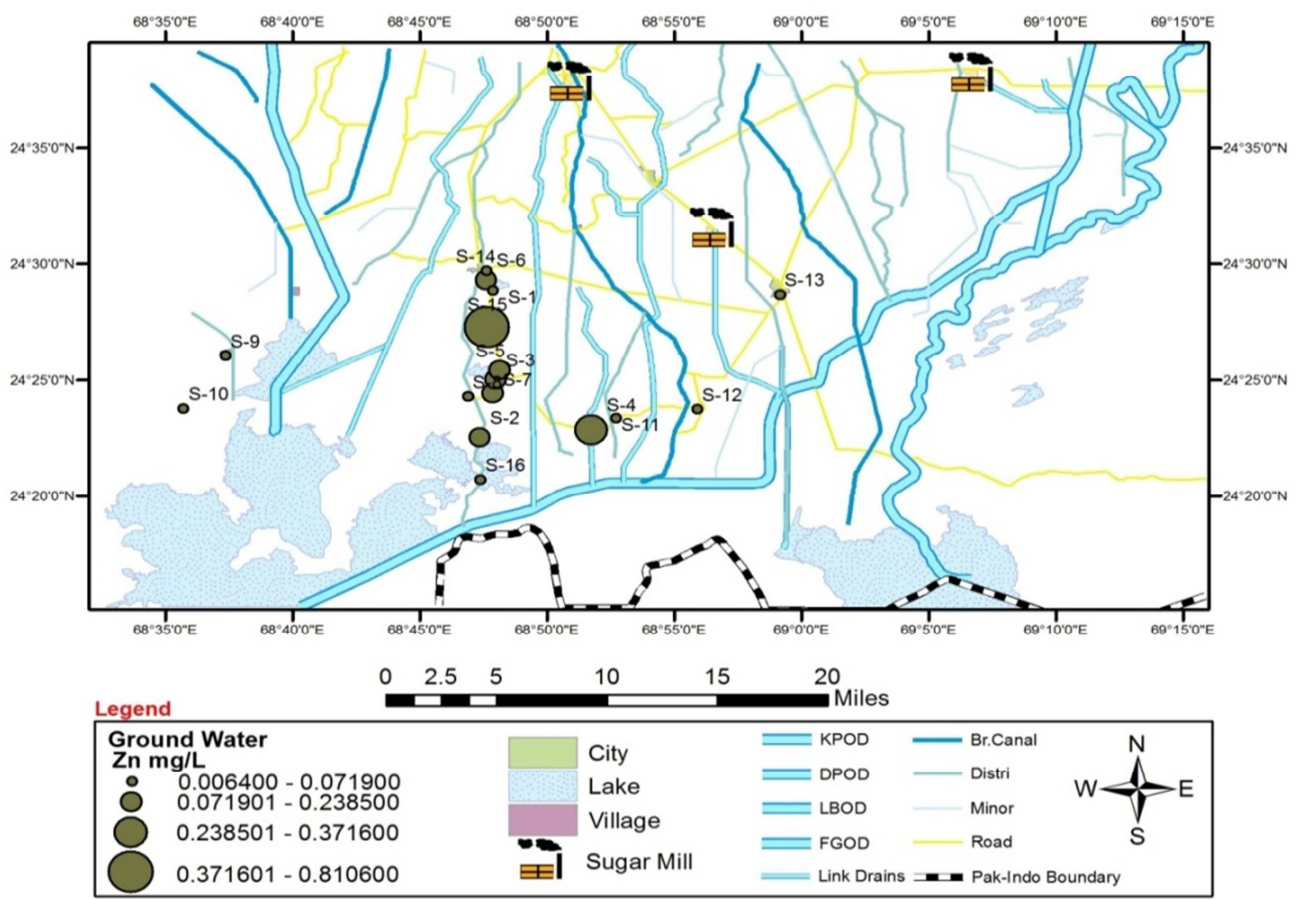

Fig. 5. Map showing Zinc detection. 


\subsection{Zinc}

Zinc is a vital element for plant food. It is present in water and soil as an organic complex and inorganic salt. $\mathrm{Zn}$ is essential for human growth, sexual development, wound healing, and fighting infection. Zinc deficiency results into retardation of growth. Exceeded concentration of zinc causes fever, depression, malaise, cough, vomiting and headache $[15$, 16]. The permissible limit for $\mathrm{Zn}$ recommended by $\mathrm{WHO}$ is 5 $\mathrm{mg} / \mathrm{L}$ [13]. The results as shown in Fig.5 indicate the concentration of zinc in graduated circles, chosen from symbology of arc map. The zinc ranged from $0.006-0.81$ $\mathrm{mg} / \mathrm{L}$. All values are shown in green colors as all values are within safe limits for drinking water as described by WHO ( $4 \mathrm{mg} / \mathrm{L}$ ). High concentration of zinc was found at S-1 area.

\subsection{Cobalt}

Cobalt is found in low concentration in the Earth's crust

\section{Coastal Area Badin}

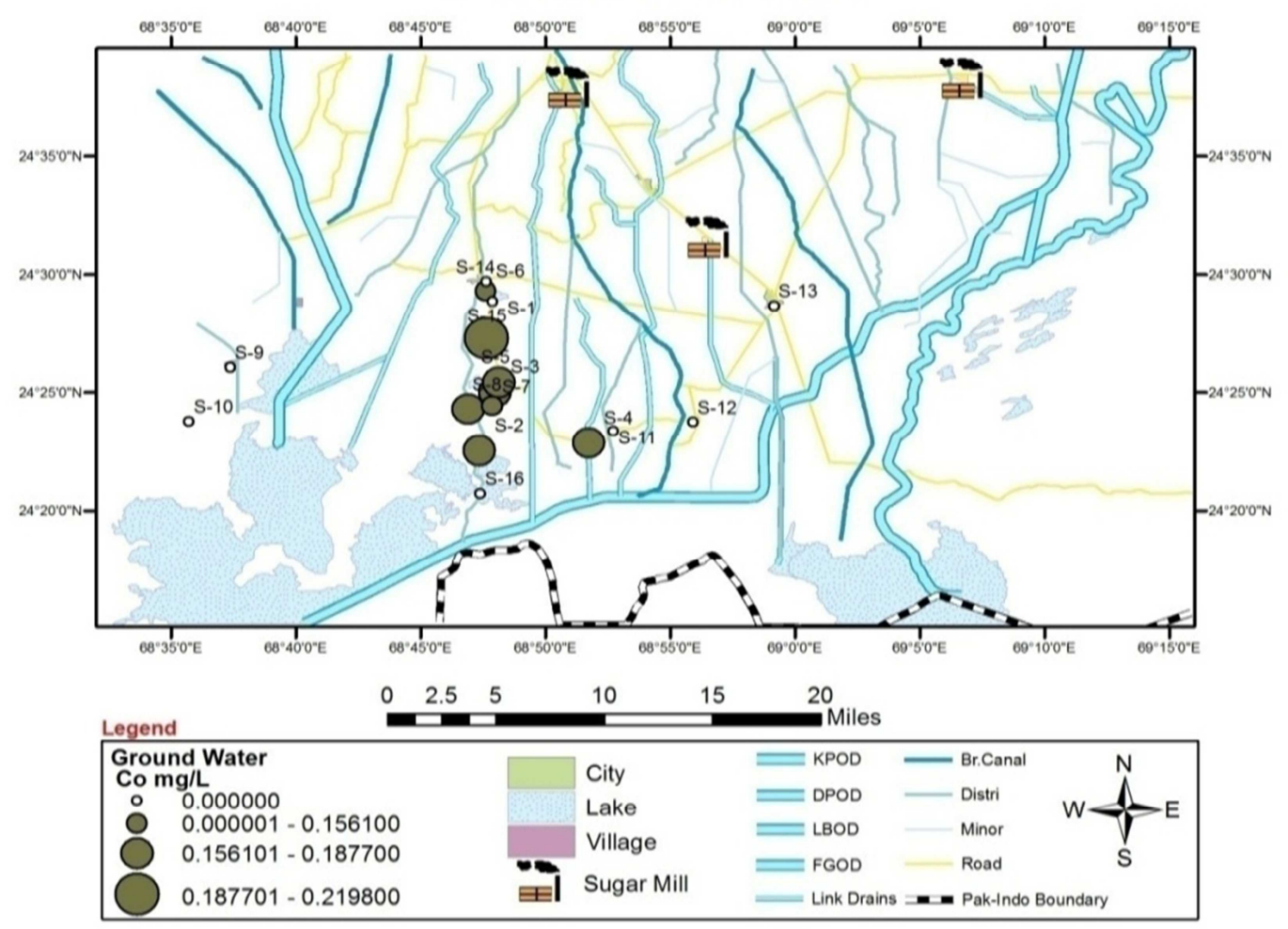

Fig. 6. Map showing cobalt detection.

\subsection{Cadmium}

The major sources of $\mathrm{Cd}(\mathrm{II})$ contamination are batteries, fertilizers, electroplating,smelting, paint pigments, miningand alloy industries $[19,18]$.Cadmium is highly toxic heavy metal for humans as well as for environment. It causes bone diseases and cancer. Chronic exposureto high concentration of cadmium causes renal dysfunction,bone degeneration and liver damage [20,21].The maximum permissible concentration of cadmium in drinking water is $0.005 \mathrm{mg} / \mathrm{L}$ recommended by WHO. Higher concentration in drinking and in natural waters. It is widely dispersed in the environment and humans can be exposed to it by breathing air, drinking water and eating food containing cobalt. Cobalt is beneficial for humans because it is a part of vitamin $B_{12}$ which is essential for human health. Cobalt is used to treat anemia in pregnant women, because it stimulates the production of red blood cells. The total daily intake of cobalt is variable and may be as much as $1 \mathrm{mg}$, but almost all will pass through the body unabsorbed, except vitamin $\mathrm{B}_{12}$. High concentration of cobalt also damages human health. The symptoms of high consumptions of concentrations of cobalt are vomiting, nausea also vision and heart problems and thyroid damage $[17,13,18]$. The results of the concentration of cobalt as shown in Fig. 6, with graduated green circles. Cobalt Co was not detected in 50\% samples. Average cobalt range was $0.0900 \mathrm{mg} / \mathrm{L}$ (Table $1 \& 2$ ). 


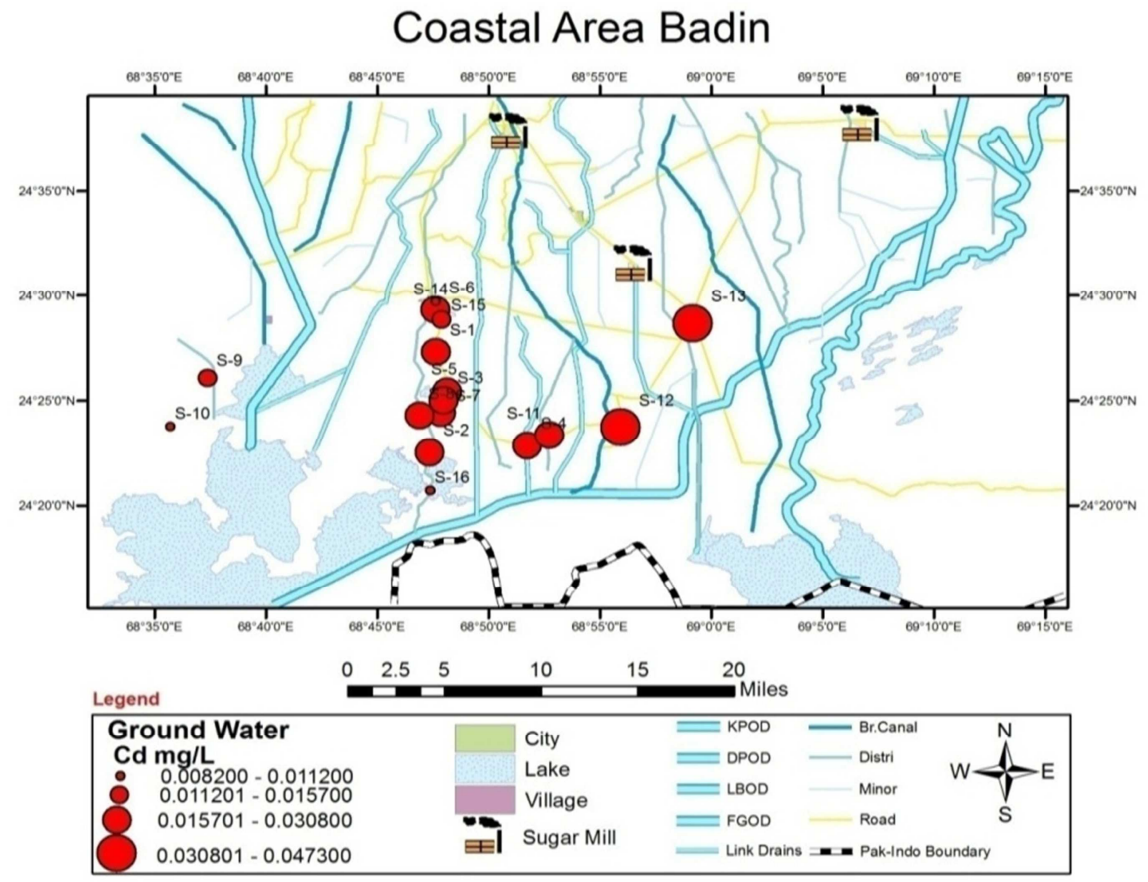

Fig. 7. Map showing Cadmium detection.

\subsection{Nickel}

Nickel is mainly used in the production of stainless steel and nickel alloys. Nickel is carcinogenic if present in high concentration. Water pipes also contribute significant amount of nickel to the environment. WHO valueof $1.0 \mathrm{mg} / \mathrm{L}$ is considered to be safe for individuals who are sensitive to $\mathrm{Ni}$ [25]. The nickel in the groundwater could be due to the contamination from municipal sewage sludge, waste water from sewage treatment plants and groundwater near landfill sites. Nickel plays an essential role in metabolic processes of higher plants $[26,18]$. The result of the concentration of nickel shown in Fig.8 indicates that concentration of $\mathrm{Ni}$ is within limits of WHO $(0.07 \mathrm{mg} / \mathrm{L})$ for drinking water. The nickel was only detected in three sampling areas. Average nickel concentration was $0.0055 \mathrm{mg} / \mathrm{L}$.

\section{Coastal Area Badin}

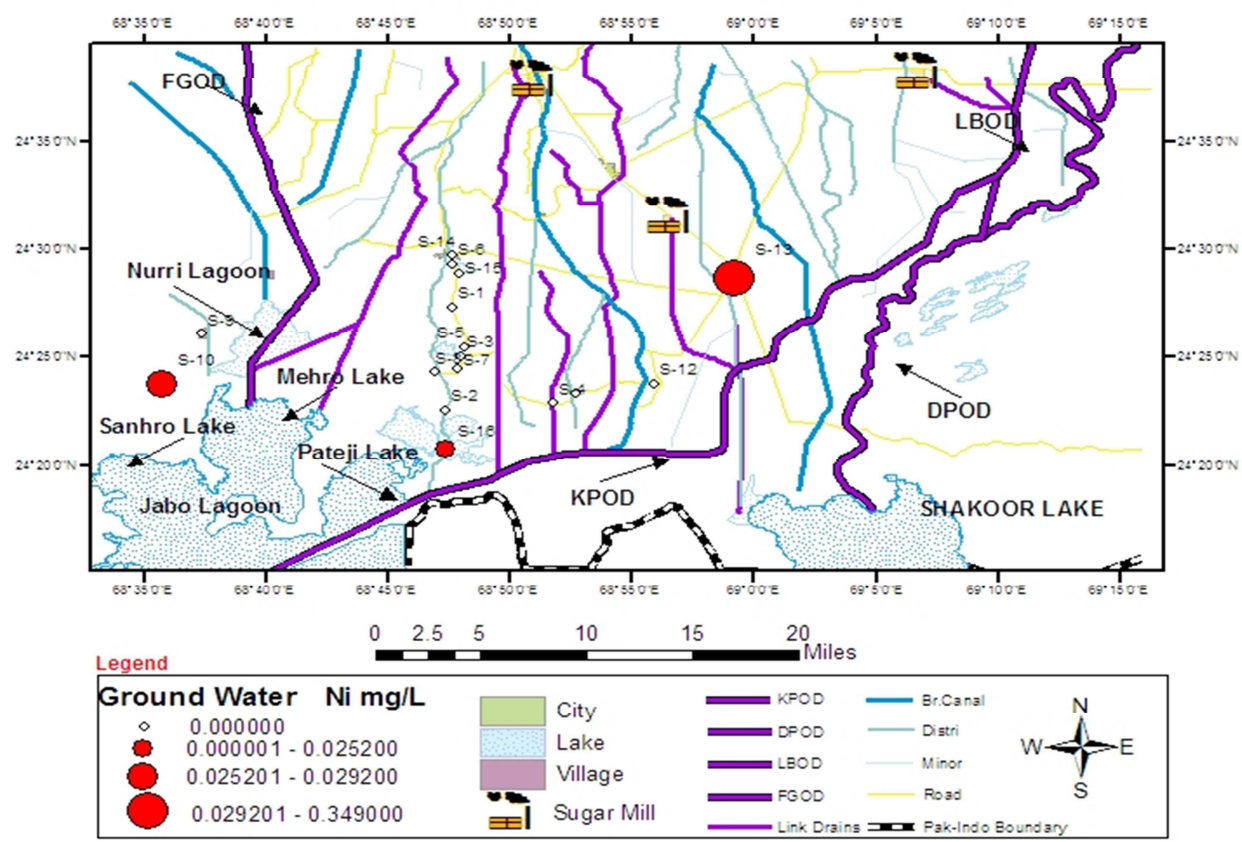

Fig. 8. Map showing detection of Nickel. 


\subsection{Iron}

It is found in natural fresh waters at levels ranging from 0.5 to $50 \mathrm{mg} / \mathrm{l}$. Anaerobic groundwater may contain ferrous iron at concentrations up to several milligrams per litre without discoloration or turbidity in the water when directly pumped from a well. There is usually no noticeable taste at iron concentrations below $0.3 \mathrm{mg} / 1$, although turbidity and color may develop. Iron is vital for human health. Iron is mainly present in soluble ferrous iron and insoluble ferric iron form in water. Water containing ferrous iron is clear and colorless. Iron helps in supplying oxygen to the blood. Dissolved ferrous iron has a disagreeable taste, when iron combines with tea and other beverages $[16,15]$.The threshold limit for iron recommended by WHO is $0.3 \mathrm{mg} / \mathrm{L}$ [13].

The results of the concentration of Fe are shown in Fig. 9 represented with graduated circles. The concentrations below threshold limits described by WHO are represented by green colored circles and values beyond threshold limits are indicated with red. The concentration of iron was found to be higher in $25 \%$ samples (S-1, S-2, S-7, and S-13) than permissible threshold limits of $\mathrm{WHO}(0.3 \mathrm{mg} / \mathrm{L})$. Sample S-1 indicated maximum concentration of iron. Higher concentration of $\mathrm{Fe}$ at these sites may be due to geochemical reasons. The results coincided with the findings of Memon $[5]$.

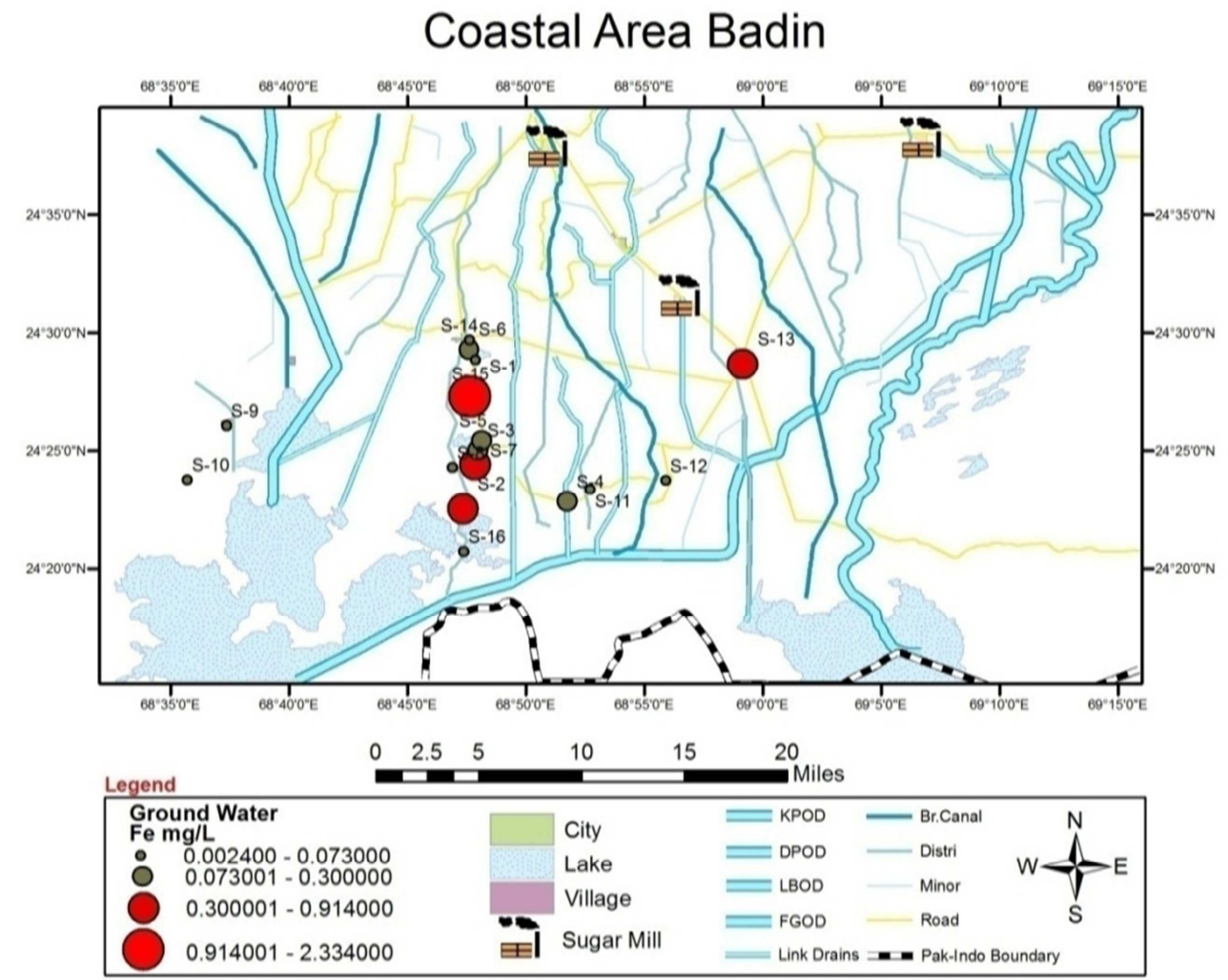

Fig. 9. Map showing iron detection.

\subsection{Lead}

Lead is present in air, soil, and water due to fossil fuel burning, mining, and manufacturing.Lead isused in different ways. It is used to produce batteries, ammunition, metal products like solder and pipes, and X-ray shielding devices. Lead is considered as a carcinogen. Lead is harmful for human body. It is toxic to nervous system too. Lead is not only considered highly toxic but a major pollution indicator. It can accumulate in the skeleton and pregnant woman are more susceptible to its adverse health effects. The lead is also used in the production of solder and alloys. The permissible WHO value for lead is $10 \mathrm{ppb}[13,17]$.

The results of the concentration of $\mathrm{Pb}$ shown in Fig. 10 are highlighted in graduated green circles. The $\mathrm{Pb}$ results obtained were within permissible limits of WHO $(10 \mu \mathrm{g} / \mathrm{L})$ for drinking water. Lead was found only in 50\% samples. Sample locations S-2, S-4, S-7, S-8, indicated high concentration of lead. The $\mathrm{Pb}$ ranged $0.2-0.4 \mu \mathrm{g} / \mathrm{L}$. The higher concentration of lead in the water of these sites can be fatal for native people and livestock, who consume it. 


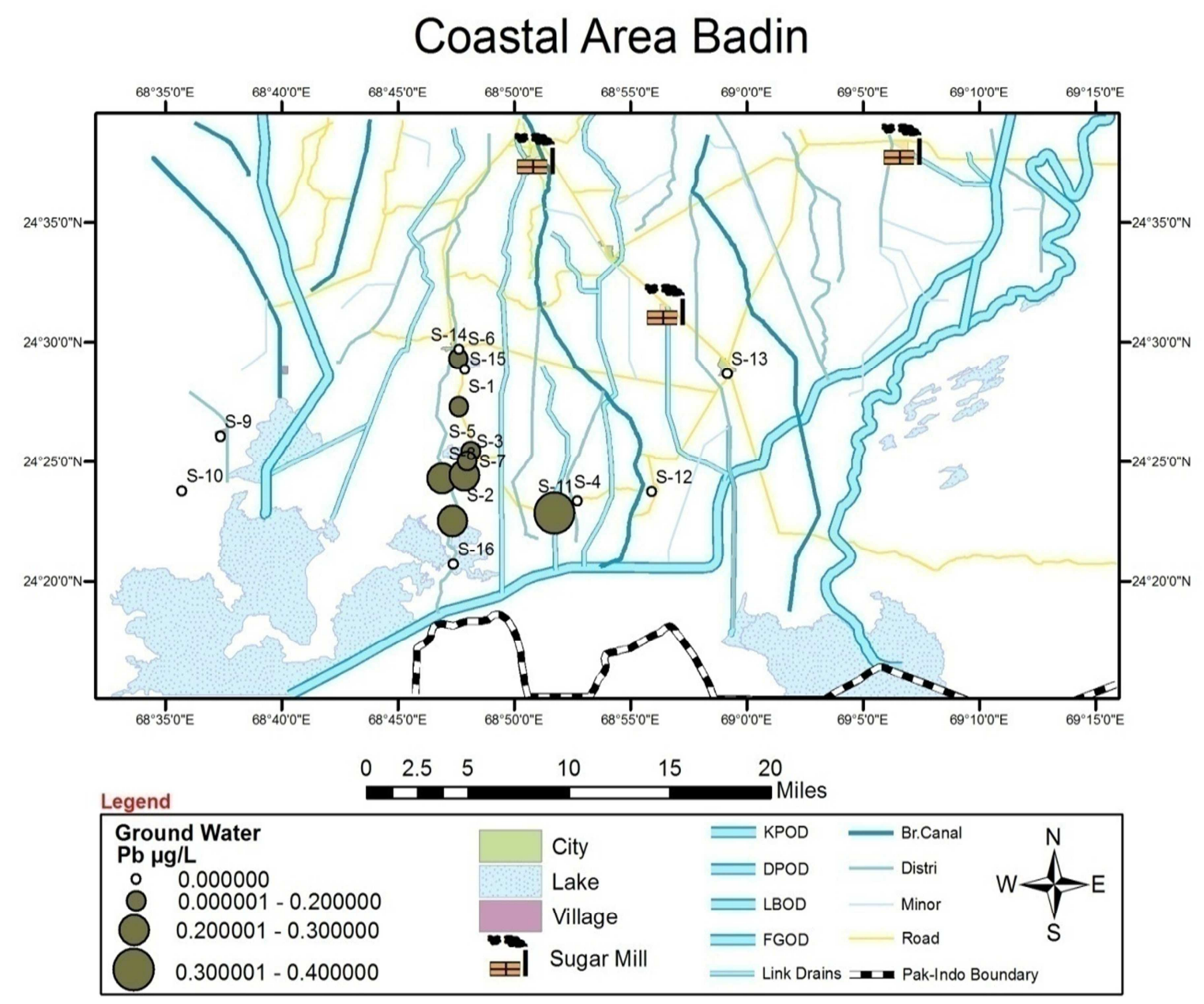

Fig. 10. Map showing Lead detection.

\section{Conclusion and Recommendations}

The present study has confirmed that there are affects of seawater intrusion or existence of trapped seawater in the coastal area of Badin. Increased parameters like TDS, EC, show near resemblance with coastal sea waters. All sampling locations had E.C beyond the permissible limits of WHO for drinking. TDS was also crossing the permissible limits of WHO except two sample locations S-14, S-15. Present results confirmed the claim of natives that hardly ten years ago they had such a brackish ground water. It also indicate that ground water suction facilitate brackish water of coastal areas though other factors also cannot be ruled out as coastal cyclones.

In addition, the LBOD has proved facilitator in increasing salinity and toxic pollutants in the coastal area of Badin. It is main source, carries industrial effluents along with agriculture run off and municipal liquid waste. Studied heavy metal results indicated that almost all parameters were within permissible limits except $\mathrm{Cd}, \mathrm{Fe}$ and Ni. Ground water is being recharged by sea tidal water and LBOD. Drainage net work carrying industrial effluents must be brought under observation through the environmental protection acts of Pakistan1997.
If the extraction of the ground water continues, without recharge by fresh water, this may accelerate the seepage of brackish water from the sea into the inland areas. The shortage of canal irrigation water in the Badin coastal areas for domestic and agricultural purposes has produced worst environmental conditions. Saline water intrusion is one of its adverse consequence. In order to stop the salt intrusion it is most urgent that a continuous surface water flow must be ensured throughout the year, to coastal distributaries, natural lakes and lagoons

\section{References}

[1] Pius A, Jerome C, SharmaN (2012) Evaluation of groundwater quality in and around Peenya industrial area of Bangalore, South India using GIS techniques. Environmental Monitoring Assessment, 184:4067-4077.

[2] UNICEF 2009 Diarrhea: why children are still dying and what can be done. The United Nations Children's Fund (UNICEF)/World Health Organization.

[3] FAO (2003) Pakistan: Sindh water resources management issues and options, Investment Centre Occasional Paper Series No. 15. Food and Agriculture Organization of the United Nations - Rome. 
[4] Khattak MA, AhmedN,Qazi MA, IzharA, IlyasS, Chaudhary MN, Khan MSA, Iqbal N and waheed T ( 2012 ) Evaluation of Ground waterquality for irrigation and drinking purposes of the areas adjacent to Hudiaraindusterial drain Lahore, Pakistan. Journal of Agriculture Sciences. 49:549-556.

[5] Memon, M.,Soomro ,M. S., Akhtar,M. S.,Memon, K.S., (2010). Drinking water quality assessment in Southern Sindh (Pakistan) Journal of Environmental Monitoring Assessment,doi: 10.1007/s10661-010-1616-Z.

[6] SIDA (2013) Sindh Water Sector Improvement ProjectI.Regional master plan of Indus delta and coastal zone.Revival of Natural DhorasSindh Water Sector Improvement Plan for Left Bank of Indus, Delta and Coastal Zone.

[7] LBOD (2005) Review of the Performance of the Left Bank Out fall Drain Stage 1 (KPOD, DPOD, Tidal Link and Cholri Weir) Report of the World Bank International Panel of Experts South Asia Region. Agriculture and Rural Development.

[8] IUCN (2006) District Vision-Badin. A Framework for Sustainable Development.

[9] EIA (2012) Environmental Impact Assessment for Exploration Activities in Badin Concession - Protected Area Final report.

[10] APHA (1989) Standard Methods for the Examination of Water and Wastewater. 17th edition American Public Health Association Washington D.C.

[11] Baalousha HM (2011) Mapping groundwater contamination risk using GIS and groundwater modeling: A case study from the Gaza Strip, Palestine. Arabian Journal of Geosciences 4: $483-494$.

[12] Arnous MO, \& El-Rayes AE (2013) An integrated GIS and hydro chemical approach to assess groundwater contamination in West Ismailia area, Egypt. Arabian Journal of Geosciences 6:2829- 2842

[13] WHO (2011) Guidelines for Drinking-water Quality $4^{\text {th }}$ edition. World Health Organization, Geneva.

[14] Ellenhorn, M.J., Barceloux, D.G. (1988). Medical toxicology: diagnosis and treatment of human poisoning. New York, Elsevier Science publishing company.
[15] Farid S, Baloch MK and AhmadSA (2012) Water pollution: Major issue in urban areas.International Journal of Water Resources and Environmental Engineering. Vol. 4(3) 55-65.

[16] Shakirullah M, Ahmed I, Mehmood K, Khan A, Rehman H, Alam S, Shah A A (2005) Physicochemical Study of Drinking Water from Dir Districts. Journal of Chemical Society of Pakistan. 27(4):374-387.[17] WHO(1993) Guidelines for drinking water quality, $2^{\text {nd }}$ Ed. Vol. 1. World Health Organization, Geneva.

[17] Khuhawar M Y and Majidano S A (2011) An Investigation of Quality of Groundwater of TalukaNawabshah. Pakakistan Journal of Chemistery. 1(2):65-71.

[18] Iqbal M, Edyvean RGJ, (2005) Loofah sponge immobilized fungal biosorbent a robust system for cadmium and other dissolved metal removal from aqueous solution. Chemosphere $61,510-518$.

[19] Devnani H, SatsangeeSP(2014) Green gold nano particle modified anthocyanin-based carbon paste electrode for voltammetric determination of heavy metals. International Journal of Environmental Science and Technology. DOI10.1007/s13762-014-0497-z

[20] Iqbal M, Saeed A, Zafar SI (2007) Hybrid biosorbent, an innovative matrix to enhance the biosorption of Cd (II) from aqueous solution. Journal of Hazard Materials. 148:47-55.

[21] Qadeer R (2004) Pollution in drinking water, their sources, harmful effects and removal procedures. Journal of ChemicalSoceity of Pakistan. 26: 293-301.

[22] WHO(1996) Guide lines for drinking-water quality. Health Criteriaand other supporting information. 94/9960Mastercom/wiener verlag-800, Australia.

[23] APHA (1995) Standard methods for the examination of water and wastewater. American Public Health Association, 19th Ed. Washington.

[24] Jennings G D, Snead RE, St Clair MB (1996) Metals in drinking water. Pub; No AG 473-1, North Carolina Cooperative Extension Service.

[25] Brown PH, Welch RM and Cary EE (1987) Plant Physiology. 85: 801-803. 